\title{
Optimization of Digital Technology to Create Accessible Learning in Universities
}

\author{
Tio Tegar Wicaksono, Indira Kusumawardhani, Kaysha Ainayya Sasdiyarto \\ UKM Peduli Difabel Universitas Gadjah Mada \\ Sleman, Indonesia \\ tio.tegar.wicaksono@mail.ugm.ac.id, indira.k@mail.ugm.ac.id,k.ainayya@mail.ugm.ac.id
}

\begin{abstract}
Education is a right for all and thus quality education resources must be provided for students. University as a high education institution yearly receives wide ranges of students with different learning backgrounds and needs, include students with disabilities. Challenges that may arise come from the unawareness of the university in identifying the needs of students with disabilities where now digital technology is readily available to be used. This paper evaluates the optimization of digital technology as learning tools to facilitate students with disabilities and authors will provide suggestions for universities to fully optimize the appropriate digital technology based on previous research. Findings were gathered through several unstructured interviews with disabilities students and review of existing researches on the related subject. There is a gap between readily available digital technology for accessible learning and the enactment that will support best education experience for students with disabilities. Several reasons why the gap occurred are the flaw of web designs and not all lecturers use the available features. Past researches have suggested several necessary designs by users with disabilities. The full use of digital technology in education is a must for all lecturers to facilitate all students by employing policies in university scale.
\end{abstract}

Keywords-accessibility; inclusion education; e-learning; disability.

\section{INTRODUCTION}

Indonesia accepts wide ranges of students who pursue higher education. Juridically, according to Act Number 12 Year 2012 on Higher Education [1] states that "higher education" is defined as "education after secondary education which includes diploma programs, undergraduate programs, master programs, doctoral programs, and professional programs, as well as specialist programs, organized by universities based on Indonesian national culture." (Article 1 (2)), and "state university" shall mean "Universities established and / or organized by the Government."

Among the students of universities are students with disabilities, whose methods of learning need to be adjusted accordingly to their respective needs. This is linked to the urge for accessible education for the students with the disabilities as one of the problems that need to be tackled by universities. If it is not solved by using adequate and sufficient facilities and measures, it will be able to lead to ineffective higher education experience for students with disabilities [2]. Therefore, one of the ways of adjusting is to implement reasonable accommodations at university scale for the students with disabilities through e-learning [3]

E-learning, as one of the schemes comes from the information and communication technologies (ICT) [4] come in different formats and compositions, and they are readily available for universities to use. To understand what e-learning is, some definitions will be provided as follows. According to European Union, e-learning mean "the use of new multimedia technologies and the internet to improve the quality of learning by facilitating access to resources and services as well as remote exchanges and collaboration [5]." Other publication says that e-learning is "a computer based educational tool or system that enables you to learn anywhere and at any time [6]." Through the decades, the development of e-learning emerged since the 1980s and 1990s through electronic educationComputer-Based Training (CBT) which eventually lead to the vast of internet use [7]. Another definition of e-learning refers to "any electronically assisted instruction but is most often associated with instruction offered via computer and the Internet" [8]. Briefly, it became the prominent way of learning since the 1960s, because of the works of Stanford University scholar Patrick Suppes and Don Bitzer from University of Illinois [9]. The motivation was that time, it was to have a more personalized study or tutor for the learners by using individualized instruction and dialogue [9]. Now, developments of e-learning are occurring. Through the years, it became more about the purpose of e-learning would be available "anywhere, anytime, and just-in-time" and became more integrated with various learning experiences and support the term e-learning [9]. Since it has been providing the Internet audience with diversified content of topics, it resembles learning in the conventional classrooms [10]. It has been shown that e-learning has given much benefits for the users as it creates ease of accessing of information. As one scholar, Bates in 1997 stated, technology has served numerous purposes in higher education; "(1) improving the quality of learning; (2) improving access to education and training; (3) reducing the costs of education; and (4) improving the cost-effectiveness of education" [11]. Therefore, e-learning is one of the leading solutions to improve the facilities for students with disabilities, also in the higher education level. The United Nations Convention on the Rights of Persons with Disabilities (UNCRPD) as one of the international legal instruments has provided state parties of the convention, Indonesia included, to adopt certain measures to ensure that the rights of people with 
disabilities are protected and enforced, not excluding education and technology rights [12]. One of the practical enforcements of this provision can be done by using Web Content Accessibility Guidelines (WCAG) that provides "a single shared standard for web content accessibility that meets the needs of individuals, organizations, and governments internationally", in which it will be discussed further in this paper.

Accordingly, state universities in Yogyakarta have been the research center of this paper. As one of the student cities in Indonesia, Yogyakarta is home for these three state universities; Universitas Gadjah Mada (UGM), Universitas Negeri Yogyakarta (UNY), and Universitas Islam Nasional Sunan Kalijaga (UINSUKA). In these universities, there are students with disabilities that registered amongst different faculties. Direct interviews have been conducted with representatives of students with disabilities in each university. This research puts focus on university students' experiences of using technology on lectures whom are blind or deaf. Similarly, a research on accessibility in higher education in Yogyakarta has previously been concluded in four state universities; Institut Seni Indonesia (ISI), UGM, UNY, and UINSUKA [2]. However, the paper reported by Soleh focuses more on accessibility in universities in macro scale; general concepts on disability, on the paradigms of disability in Indonesia, types of educations that suit with the needs of students with disabilities, higher education accessibility rights, and the policies for facilitating students with disabilities in each university. It also focuses on blind, deaf, and motoric/physical disabilities. Because of that, this paper investigates and proposes solutions in what ways of the technical aspects of e-learning as well as the policy aspects from universities toward accessible studies to the students with disabilities, and how the policy can be implemented by the higher education practitioners i.e. the lecturers.

\section{METHOD}

In this paper, the main aspects of accessibility that are going to be discussed are Evaluation of the utilization of technology, specifically e-learning in the teaching and learning processes, and optimization of digital technology based on Web Content Accessibility Guidelines (WCAG), specifically for e-learning in the teaching and learning process

Therefore, the two research questions constructed are as follows:

Q1: What is the state of accessibility in e-learning platforms in the respective universities?

Q2: How to improve the current state of accessibility in elearning platforms in the respective universities?

This paper is to disclose the ways on how to provide the better facilities for students with disabilities in higher education with the spirit of protecting and enforcing the rights of people with disabilities.

\section{A. Procedures}

To reach the purpose of this paper, primary data and secondary data will be used. In getting primary data, unstructured interviews to students with disabilities in UGM, UNY, and UINSUKA that have access to and are using elearning in their studies were conducted. For secondary data, this paper obtains materials on what the best e-learning platforms would be from online journal and books regarding accessible higher education, guidelines for accessible websites. Besides that, this paper refers to national and international regulations in order to emphasize the educational rights and rights for information and technology for students with disabilities in higher education.

\section{B. Participants}

The participants of this research are deaf and blind students of UGM, UNY, and UINSUKA who have the experiences in accessing e-learning platforms in studying at their universities.

\section{Data Analysis}

The approach on analyzing the data gathered from the interviews and literature review is exploratory data analysis which exposes the real situations faced by the interviewees from the interview section, as well as to uncover what best practices in technical development so that websites can be accessible to be used by students with disabilities across universities.

\section{RESULT AND DISCUSSION}

Research conducted by Kendall said that students with disabilities often have difficulties in participating of learning if the lecturer has not uploaded lecture material before the lecture begins [13]. Students with disabilities also often feel reluctant to ask lecturers who have not yet used e-learning media to use it because they are worried for a perceived special treatment [13].

Evaluations are based on the following interview results. An interview is conducted with a deaf student named Muhwin Althof from Faculty of Animal Sciences, UGM. Althof tells us about how he uses e-learning to support his education at the university.

According to Althof, it is unfortunate because there are only a few lecturers who use e-learning learning media. In fact, according to Althof, e-learning media is very helpful for deaf students. For example, by using e-learning media, deaf students can change the oral exam to a written format.

Elisa (elisa.ugm.ac.id) is an e-learning platform provided by UGM which serves to support learning. Through Elisa, students and lecturers can interact through discussions, upload assignments, share class material, and even conduct computerbased quiz or exam. Althof can ask for the help of his classmates if he has difficulty in understanding the lecture material in the form of delivering material from the lecturer or video playback which is presented without subtitles.

At UNY, we conducted an interview with a blind student named Imam Budi Prasetyo. Imam said that UNY has an e- 
learning platform called Besmart. Through Besmart, students can upload college assignments while lecturers can upload lecture material.

Even though it can be used to upload task files and lecture material, it cannot be used to conduct discussion between lecturers and students. As a result, lecturers and students cannot interact through e-learning media.

Regarding its use, Imam used the e-learning platform only for the first three semesters. This is because after three semester the lecturer never used it again and even the platform had suffered some error.

In UINSUKA, interviews were also conducted with a student with a visual disability. The fact is not much different from those at UGM and UNY. Dedi Arya Nugraha, student of Raudlatul Atfal Teacher Education said that throughout his classes, there were only three lecturers who used the e-learning media. Whereas according to him, the platform is actually very helpful if it is optimized. Students can upload assignments while lecturers can upload lecture material. There is a comment feature that can also be used virtually, but it has never been used at all.

The blind students can access soft files with the help of screen reader software in laptops. The visually impaired students can utilize audio medium to access the digital media [14]. The use of e-learning media is actually a form of universal design learning. Universal design is one of the rights set out in the legislations in Indonesia [15]. More detailed universal design regulated in Law No. 8 of 2016 concerning Persons with Disabilities and Minister of Research and Higher Education Regulation No. 46 of 2017.

From the explanation above, the optimization of the elearning platform that has been available is not implemented properly. The lack of use of e-learning media by lecturers is a point that must be evaluated in the use of e-learning in learning and teaching activities.

\section{A. Design Improvements for Accessibility}

There have been many guidelines made for the purpose of making the web accessible for all users. One of the most popular standards of web accessibility is the Web Content Accessibility Guidelines (WCAG). WCAG lists several checkpoints that should be completed by creators (i.e. web developers, web designers, etc.) so any user can access the web comfortably [16]. WCAG have several guidelines which works under 4 basic principles: perceivable, operable, understandable, and robust.

\section{1) Perceivable}

Perceivable principle demands that any information and user interface components must be presentable to users in ways they can perceive. Any non-text contents such as images, data charts, etc., need to have accompanying description or text alternatives that can be translated by assistive technology into formats that can be perceived by user (e.g. audio description, braille, etc.). Text alternatives can also be used as labels to identify audio, video, and files in other formats, as well as applications that are embedded as part of a website.
For users who cannot perceive audio or video, there is also a need for alternative formats such as transcripts, sign languages interpretation, or captions for audio-content and audio description for visual details on video.

\section{2) Operable}

Many assistive technologies depend on keyboard-only interaction. In the other words, the design of the web must be able to use the keyboard interface to access all part of the web. Example of keyboard control includes using arrows and tab button. It is also important to note that flashing content must be avoided because such content on the website can cause seizure.

\section{3) Understandable}

Information on the web must be easily understood by users. Identifying language can be easily read by screen reader and also in defining unusual words. Predictable interface is also ideal, because users can easily assign shortcuts for easier navigation. Some functions may be confusing for many people, and mistakes can easily happen. Descriptive instructions such as error messages can be helpful in the event of a mistake happening.

\section{4) Robust}

Robust content means that it is "compatible with different browsers, assistive technologies, and other user agents". User agents here means software that user use to access the web, like desktop browser, mobile browser, etc.

\section{B. Policy is a Must}

It is not enough to only rely on the sufficiency on the technical quality of the e-learning platforms. Universities need to impose concrete policies enforceable to every level of the university [17]. In this paper, it is acknowledged that policy can be used in the direction of 'top-down' or 'bottom-up' [18]. However, this paper aims to concentrate on the 'top-down' policy scheme as it is the most realistic approach to establish a holistic accessible learning environment for the students with disabilities in universities. The two following suggestions are taken as measures educating and training the lecturers on the use of accessible e-learning platforms to teach, as well as implementing obligatory rules towards the lecturers to use them.

Lecturers can upload all teaching materials into the elearning platforms that are also used as a discussion forum for the students and lecturers. This can help students with disabilities such as Althof, Prasetyo and Nugraha inclusive in the overall teaching and learning process together with the students with have no disabilities within the same classrooms and courses. The education and training must also ensure to increase the willingness of the lecturers to provide accessible learning experience for students with disabilities.

To ensure that the aforementioned education and training are sustainable, Rectors are the highest power holders in the universities who can enforce decrees stating that lecturers in the teaching and learning process in every course must employ accessible e-learning platforms in the classrooms as well as outside of classrooms. 


\section{CONCLUSION}

The three students interviewed basically said the same things, which e-learning platforms have not been utilized in maximum capacity in learning process and the design of the websites in their respective universities cannot entirely support their learning process.

According to the WCAG, the design of the web must adhere to four principles: perceivable, operable, understandable, and robust. For example, the websites should be presented in a way any users can perceive, operable using keyboard control, easily understood, and compatible with any software.

Other approach to optimize the already developed elearning platforms is through implementing university-scale policies. For example, the needs of all lecturers to integrate learning process with e-learning platforms.

\section{REFERENCES}

[1] U.U.R. Indonesia, Undang-Undang Republik Indonesia Nomor 12 Tahun 2012 Tentang Pendidikan Tinggi, 2012.

[2] A. Soleh, "Kebijakan perguruan tinggi negeri yogyakarta terhadap penyandang disabilitas," Jurnal Pendidikan Islam, vol 3, no 1, pp. 1, 2014.

[3] K. Kumar, P. Ravi, and P. Srivatsa, "Effective e-learning approach for students with learning disabilities," International Journal of Scientific \& Engineering Research, vol 2, no 11, p. 1, 2011.

[4] S. G. Rosenblit, “Distance education' and 'e-learning': Not the same thing," Higher Education, vol 49, no 4, p. 467, 2005.

[5] S.G. Rosenblit and B. Gros, "E-learning: confusing terminology, research gaps and inherent challenges," International Journal of ELearning \& Distance Education, vol 25, no 1, 2011.
[6] L. L. C. Epignosis, E-Learning concepts, trends, applications, 2014

[7] S. Hubackova, "History and perspectives of elearning," Procedia Social and Behavioral Sciences, vol 191, pp. 1187-1190, 2015.

[8] H. H. Yang, "New world, new learning: trends and issues of e-learning," Procedia-Social and Behavioral Sciences, vol 77, pp. 429-442, 2013.

[9] P. Nicholson, A history of e-learning, Computers and education, Dordrecht: Springer, 2007.

[10] P. Honey, "E-learning: a performance appraisal and some suggestions for improvement," The learning organization, vol 8, no 5, pp. 200-203. 2001.

[11] S. Alexander, "E-learning developments and experiences," Education+ Training, vol 43, no (4/5), pp. 240-248, 2001.

[12] A. Hendricks, "UN convention on the rights of persons with disabilities," Eur. J. Health L, vol 14, pp. 273, 2007.

[13] L. Kendall, "Higher education and disability: exploring student experiences," Cogent Education, vol 3, no 1, 2016

[14] A. C. Frobenius, and E. R. S. HS. "Kacamata berbasis max sonar terintegrasi dengan aplikasi mobile android untuk memberikan navigasi tunanetra menggunakan jaringan bluetooth, " Semnasteknomedia Online, vol 6, no 1, pp. 1-10, 2018.

[15] R. Harahap, I. D. Wahyudi, and W. Martokusumo, "Inovasi akses assistive technology untuk mahasiswa disabilitas pendengaran dengan pendekatan prinsip universal design," In: Seminar Nasional Seni dan Desain 2017, 2017.

[16] B. Caldwell, M. Cooper, L. G. Reid, and G. Vanderheiden, Web content accessibility guidelines (WCAG) 2.0, WWW Consortium (W3C), 2008.

[17] D. Sloan, S. Horton, and B. Gregory, "Masterplanning the digital campus to support learners with disabilities," In Proceedings of the 13th Web for All Conference, p. 31, 2016.

[18] D. Freitas, Sara, and O. Martin, "Does e-learning policy drive change in higher education?: a case study relating models of organisational change to e-learning implementation," Journal of Higher Education Policy and Management, vol 27, no 1, pp. 81-96, 2005. 